\title{
Pengaruh pemanfaatan internet terhadap minat kunjung pemustaka ke Unit Pelaksana Teknis (UPT) Perpustakaan Universitas Islam Negeri Sulthan Thaha Saifuddin Jambi
}

\author{
${ }^{1}$ Elva Jelita, Raudhoh ${ }^{2}$, Masyrisal Miliani ${ }^{3}$ \\ ${ }^{1,2,3}$ Fakultas Adab dan Humaniora Universitas Islam Sulthan Thaha Saifuddin Jambi \\ Jalan Jambi - Muaro Bulian Km.16, Muaro Jambi, 36363 \\ e-mail: Elvajelita6@gmail.com
}

\begin{abstract}
Introduction. The purpose of this study was to determine whether there is an effect of internet use on student interest in visiting the UPT Library of the State Islamic University of Sulthan Thaha Saifuddin Jambi..

Data Collection Method. This research is a descriptive quantitative research with data collection techniques, namely observation, questionnaires and documentation. The population in this study were students who were active in the library of the State Islamic University of Sulthan Thaha Saifuddin Jambi. While the sample used the Slovin formula with accidental technique with a large sample of 99 people.

Analysis Data.The data analysis technique is descriptive analysis, simple linear regression test, hypothesis testing and determination test.

Results and Discussions. Based on the analysis of the percentage score on the internet utilization variable, it was obtained a score percentage of $81.46 \%$ in the $81.25 \%-100 \%$ interval, which means that the use of the internet is included in the very good category. While the interest in visiting was obtained by a percentage score of $79.1 \%$ in the interval $62.50 \%-81.24 \%$ which means that the interest in visiting is in the good category. Based on the simple linear regression test, there is an influence between internet use and visiting interest, the equation $Y=14.402+0.527 \mathrm{X}$ is obtained, if every $1 \%$ increase in internet utilization rate $(X)$ then visiting interest $(Y)$ will increase by 0.527. Based on the hypothesis test, it is obtained that t count is 5.405 and a significant value of 0.00 then Ho is rejected and $\mathrm{Ha}$ is accepted. In the coefficient of determination, it is known that the R square value of 0.231 means that the effect of internet use $(X)$ on visiting interest $(Y)$ is $23.1 \%$ while $76.9 \%$ of visiting interest is influenced by other variables not studied.

Conclusions. Based on the research that has been done, there is a strong relationship between internet use and visiting interest. . By using the internet, it makes communication easy for users, provides learning support in helping meet the information needs needed and utilizing the internet can help libraries in improving their services.
\end{abstract}

Keywords: Internet, minat kunjung, perpustakaan perguruan tinggi

\begin{abstract}
ABSTRAK
Pendahuluan. Tujuan dari penelitian ini adalah untuk mengetahui adakah pengaruh pemanfaatan internet terhadap minat kunjung mahasiswa ke UPT Perpustakaan Universitas Islam Negeri Sulthan Thaha Saifuddin Jambi.

Metode Penelitian. Penelitian ini merupakan penelitian kuantitatif deskriptif dengan teknik pengumpulan data yaitu observasi, angket dan dokumentasi. Populasi pada penelitian ini yaitu mahasiswa yang aktif ke perpustakaan Universitas Islam Negeri Sulthan Thaha Saifuddin Jambi. Sedangkan sampel menggunakan rumus slovin dengan teknik accidental dengan banyak sampel 99 orang.
\end{abstract}

Data Analisis. Adapun teknik analisis data yaitu dengan analisis deskriptif, uji regresi linier sederhana, uji hipotesis dan uji determinasi. 
Hasil dan Pembahasan. Berdasarkan analisis presentase skor pada variabel pemanfaatan internet diperoleh presentase skor sebesar $81,46 \%$ berada pada interval 81,25\% - 100\% yang berarti bahwa pemanfaatan internet termasuk dalam kategori sangat baik. Sedangkan minat kunjung diperoleh presentase skor sebesar 79,1\% berada pada interval 62,50\% - 81,24\% yang berarti bahwa minat kunjung termasuk dalam kategori baik. Berdasarkan uji regresi linier sederhana adanya pengaruh antara pemanfaatan internet dengan minat kunjung maka diperoleh persamaan $Y=14.402+0,527 X$, apabila setiap penambahan $1 \%$ tingkat pemanfaatan internet $(X)$ maka minat kunjung $(Y)$ akan meningkat sebesar 0,527. Berdasarkan uji hipotesis diperoleh $t$ hitung sebesar 5.405 dan nilai signifikan sebesar 0,00 maka Ho ditolak dan Ha diterima. Pada koefisien determinasi diketahui nilai $R$ square sebesar 0,231 artinya pengaruh pemanfaatan internet $(X)$ terhadap minat kunjung $(Y)$ adalah sebesar 23,1\% sedangkan 76,9\% minat kunjung dipengaruhi oleh variabel lain yang tidak diteliti.

Kesimpulan dan Saran. Berdasarkan penelitian yang telah dilakukan terdapat hubungan yang kuat antara pemanfaatan internet dengan minat kunjung. . Dengan memanfaatan internet memberi kemudahan berkomunikasi bagi pemustaka, memberi dukungan pembelajaran dalam membantu memenuhi kebutuhan informasi yang dibutuhkan dan memanfaatkan internet dapat membantu perpustakaan dalam meningkatkan layanannya.

Keywords: Internet, minat kunjung, perpustakaan perguruan tinggi

\section{A. PENDAHULUAN}

Dengan adanya internet di perpustakaan akan mempermudah bagi para pemustaka dalam mengakses informasi yang dibutuhkan oleh pemustaka. Di perpustakaan hanya menyediakan informasi dalam bentuk media cetak, dengan adanya internet akan lebih membantu dalam pencarian informasi dalam bentuk elektronik. Di Perpustakaan Universitas Islam Negeri Sulthan Thaha Saifuddin Jambi telah menyediakan koneksi internet yang berupa wireless fidelity untuk para pemustaka dalam mengakses internet untuk memenuhi kebutuhan informasi yang dibutuhkan. Wireless fidelity merupakan salah satu daya tarik pemustaka untuk berkunjung ke perpustakaan karena dengan adanya wireless fidelity menghemat penggunaan data internet di android para pemustaka. Pemustaka cenderung membutuhkan informasi semakin banyak dan semakin cepat untuk mengimbangi aktivitasnya yang relevan dengan apa yang mereka butuhkan. Sumber informasi yang paling banyak diakses adalah internet. Untuk itu perpustakaan sebagai penyedia jasa informasi perlu melakukan strategi internet, dengan memanfaatkan jasa layanan internet. Dengan demikian internet dapat memberi kesempatan pada pustakawan dan perpustakaan untuk menjawab kebutuhan informasi yang diperlukan. ${ }^{1}$ Pengaruh Area internet bagi pemenuhan kebutuhan informasi pemustaka di Perpustakaan Unversitas Islam Negeri Sulthan Thaha Saifuddin Jambi menyatakan bahwa area hotspot berpengaruh signifikan terhadap pemenuhan kebutuhan informasi pemustaka. Hal ini menunjukkan bahwa manfaat internet sangat penting dalam menunjang tercapainya tujuan

${ }^{1}$ D. Aditiyawarman. Analisis Pemanfaatan Wireless Hotspot bagi Pemenuhan Kebutuhan Informasi Pemustaka pada Perpustakaan Daerah Kabupaten Purwakarta. Program Studi Manajemen Informatika Akademi Manajemen Informatika dan Komputer BSI Karawang, (n.d.). Hal. 2. 
perpustakaan memenuhi kebutuhan pemustaka sehingga tingkat berkunjung meningkat setiap harinya. Dari observasi awal, mahasiswa yang berkunjung ke UPT Perpustakaan Universitas Islam Negeri Sulthan Thaha Saifuddin Jambi yaitu untuk memanfaatkan jaringan internet yang disediakan di perpustakaan. Akan tetapi di UPT Perpustakaan Universitas Islam Negeri Sulthan Thaha Saifuddin Jambi memiliki kecepatan akses jaringan internet yang masih rendah. Jika pengunjung sudah banyak datang ke perpustakaan maka jaringan internet yang tersedia akan semakin susah digunakan. Dengan banyaknya jumlah pengunjung maka perlu adanya penambahan kecepatan koneksi internet sehingga bisa digunakan oleh pengunjung dengan jumlah yang banyak. Berdasarkan survey awal, minat pemustaka ke perpustakaan Universitas Islam Negeri Sulthan Thaha Saifuddin Jambi masih rendah. Hal ini terlihat dari jumlah pemustaka yang terdaftar di perpustakaan sebanyak 16.089 orang sedangkan jumlah pemustaka yang aktif 8.129 orang. Dari sini dapat dikatakan bahwa hanya sebagian pemustaka yang aktif mengunjungi perpustakaan. Dan dari bulan September-Desember 2019 atau 1 semester jumlah pengunjung hanya sebanyak 10.382 orang. Artinya dalam 1 semester mahasiswa yang aktif saja hanya 1-2 kali mengunjungi perpustakaan. Mahasiswa juga lebih suka mengakses informasi di luar perpustakaan via internet dan terbatasnya mahasiswa dalam mengakses internet. Oleh sebab itu, peneliti mengangkat judul Pengaruh Pemanfaatan Internet terhadap Minat Kunjung Pemustaka ke UPT (Unit Pelaksana Teknis) Perpustakaan Universitas Islam Negeri Sulthan Thaha Saifuddin Jambi.

\section{B. TINJAUAN PUSTAKA}

\section{Minat Kunjung}

Kamus Kepustakawanan Indonesia mendefenisikan kunjungan ke perpustakaan adalah kegiatan memasuki perpustakaan untuk melakukan akses informasi dan kegiatan lainnya di perpustakaan yang tercatat secara manual maupun elektronik. ${ }^{2}$ Tujuan berkunjung diataranya yaitu:

a. Berkunjung untuk tujuan kesenangan. Dalam artian masyarakat datang memanfaatkan koleksi perpustakaan yang disenangi seperti, membaca novel, surat kabar, komik dan lain-lain.

b. Berkunjung untuk tujuan memperoleh sesuatu yang baru (ilmu pengetahuan)

\footnotetext{
${ }^{2}$ Lasa, Hs. Kamus Kepustakawanan Indonesia. (Yogyakarta: Pustaka Book Publisher, cet. 1, 2009).Hal. 183
} 
c. Berkunjung untuk menyelesaikan tugas atau pekerjaan. Dalam artian seseorang datang berkunjung ke perpustakaan untuk memanfaatkan fasilitas dan membaca koleksi yang ada untuk menyelesaikan tugas akademiknya ataupun tugas kantornya. Kegiatan semacam ini dinamakan Reading For Work. ${ }^{3}$

Menurut Mahmud dalam jurnal Habir, faktor yang mempengaruhi minat seseorang bisa dipengaruhi oleh beberapa hal diantaranya sebagai berikut:

a. Kondisi fisik, keadaan jasmani dan kondisi yang baik akan mempengaruhi minat yang lebih tinggi. Namun setelah adanya peristiwa, sehingga mengakibatkan seseorang mengalami cacat jasmani maka orang tersebut akan berubah minat belajarnya sehingga lebih suka kepada hal-hal yang lebih sesuai dengan kondisi dirinya.

b. Keadaan psikis, perubahan psikis seseorang mempengaruhi minat terhadap suatu bidang studi tertentu. Misalnya, dengan gangguan jasmani dan rohani, maka akan mempengaruhi keinginan yang berbeda.

c. Lingkungan sosial, lingkungan atau alam sekitar akan mempengaruhi minat meskipun dalam waktu relatif lama. ${ }^{4}$

\section{Pemanfaatan Internet}

Internet merupakan suatu gabungan dari berbagai jaringan komputer yang ada di seluruh dunia. Internet itu adalah suatu jaringan komputer yang saling terhubung dan memungkinkan adanya suatu komunikasi data antar komputer. Di Indonesia internet telah digunakan oleh beberapa perusahaan walaupun terbatas pada perusahaan komputer dan industri besar lainnya. ${ }^{5}$ Pemanfaatan internet di perpustakaan yaitu sebagai berikut:

a. Kemudahan berkomunikasi

Dengan adanya internet setiap orang dapat berkomunikasi dengan cepat, murah dan efisien. Orang bisa menggunakan komunikasi tidak langsung seperti suara elektronis, komunikasi langsung melalui chatting, ataupun bertatap muka secara elektronis melalui video konferensi.

b. Dukungan pembelajaran

Banyak program komputer yang ditunjukkan untuk mempermudah orang dalam mempelajari ilmu pengetahuan maupun bahasa asing. Dengan dukungan multimedia, ilmu-ilmu yang sering dianggap sulit dapat disajikan dalam bentuk atau cara yang

\footnotetext{
${ }^{3}$ Noerhayati Sudibyo. Pengelolaan Perpustakaan. (Bandung: Alumni, 1987). Hal. 67

${ }^{4}$ Habir. Pengaruh Layanan Perpustakaan terhadap Minat Kunjung Pemustaka di Perpustakaan STIKES Mega Rizky Makassar. Hal. 160

${ }^{5}$ Hartono. Manajemen Perpustakaan. Hal.176
} 
membuat orang senang mempelajarinya. Suatu materi juga dapat dipelajari dengan komputer tanpa harus menginstal program karena program ditaruh pada penyedia dan cukup mengunjungi situs web-nya.

c. Penghematan biaya

Pembisnis dapat menjalankan bisnis dengan harapan dapat melakukan penghematan biaya sehingga bisa menjual produk dengan lebih murah dan meningkatkan kompetensi dengan pesaing. Berbagai perusahaan bisa saling bekerja sama untuk bertukar informasi secara otomatis sehingga tidak perlu melibatkan orang lain secara khusus. Mesin otomatis dapat bekerja menggantikan peran manusia sehingga produksi menjadi lebih murah dan kualitas yang seragam bisa diperoleh.

d. Penghilang kendala waktu

e. Peningkatan layanan. ${ }^{6}$

\section{METODE PENELITIAN}

\section{Populasi dan Sampel}

Populasi penelitian merupakan keseluruhan dari objek penelitian yang dapat berupa manusia, hewan, tumbuh-tumbuhan, udara, gejala, nilai, peristiwa, sikap individu dan sebagainya. Sehingga objek-objek ini dapat menjadi sumber penelitian. Sedangkan sampel adalah suatu prosedur pengambilan data di mana hanya sebagian populasi saja yang diambil dan dipergunakan untuk menentukan sifat serta ciri yang dikehendaki dari suatu populasi. ${ }^{7}$ Populasi dalam penelitian ini adalah jumlah anggota yang aktif di UPT Perpustakaan Universitas Islam Negeri Sulthan Thaha Saifuddin Jambi sebanyak 8.129 orang. Pengambilan sampel menggunakan teknik nonprobability sampling yaitu teknik pengambilan sampel yang tidak memberi peluang/kesempatan sama bagi setiap unsur atau anggota populasi untuk dipilih menjadi sampel. ${ }^{8}$ Dengan menggunakan sampling Accidental, yaitu teknik penentuan sampel berdasarkan faktor kebetulan, yaitu siapa saja yang secara kebetulan bertemu dengan peneliti dapat digunakan sebagai sampel. Apabila orang yang kebetulan ditemui itu dianggap cocok sebagai sumber data. ${ }^{9}$ Sampel dalam penelitian ini adalah pengunjung Perpusatakaan Universitas Islam

\footnotetext{
${ }^{6}$ Hartono. Manajemen Perpustakaan. Hal. 182-184

${ }^{7}$ Syofian Siregar. Metode Penelitian Kuantitatif. (Bandung: Penerbit Alfabeta, 2018). Hal. 30

${ }^{8}$ Sugiyono. Metode Penelitian Kuanatitatif. (Bandung: Penerbit Alfabeta, 2018). Hal. 136

${ }^{9}$ Sugiyono. Metode Penelitian Kuanatitatif. Hal. 138
} 
Negeri Sulthan Thaha Saifuddin Jambi yang dianggap peneliti cocok. Dengan rumus Slovin maka banyak sampel adalah:

$$
\begin{aligned}
& n=\frac{\mathrm{N}}{1+N e^{2}} \\
& n=\frac{8129}{1+(8129)(10 \%)^{2}}=\frac{8129}{82,29} \\
& n=98,7 \text { dibulatkan menjadi } 99
\end{aligned}
$$

Dimana:

$\begin{array}{ll}\mathrm{n} & : \text { Sampel } \\ \mathrm{N} & : \text { Populasi } \\ \mathrm{e} & : \text { Perkiraan tingkat kesalahan }(10 \%)^{10}\end{array}$

\section{Instrumen Penelitian}

Pada prinsipnya meneliti adalah melakukan pengukuran terhadap fenomena sosial maupun alam. Meneliti dengan data yang sudah ada lebih tepat kalau dinamakan membuat laporan dari pada melakukan penelitian. Karena pada prinsipnya meneliti adalah melakukan pengukuran, maka harus ada alat ukur yang baik. Alat ukur dalam penelitian adalah suatu alat yang digunakan mengukur fenomena alam maupun sosial yang diamati. Secara spesifik semua fenomena ini disebut variabel penelitian. ${ }^{11}$ Untuk memperoleh data tentang "Pengaruh Pemanfaatan Internet terhadap Minat Kunjung Pemustaka ke Unit Pelaksana Teknis (UPT) Perpustakaan Universitas Islam Negeri Sulthan Thaha Saifuddin Jambi”, instrument pengumpulan data yang digunakan berupa angket yang bersekala likert.

Tabel 1. Skala Likert

\begin{tabular}{lcc} 
& Pernyataan positif & \\
\hline & Ungkapkan & Nilai \\
Sangat setuju & 4 \\
Setuju & 3 \\
Tidak setuju & 2 \\
Sangat tidak setuju & 1 \\
\hline
\end{tabular}

Skala likert digunakan untuk mengukur sikap, pendapat dan persepsi seseorang atau sekelompok orang tentang fenomena sosial. Dalam penelitian, fenomena sosial ini telah ditetapkan secara spesifik oleh peneliti, yang selanjutnya disebut sebagai variabel peneliti. Dengan skala likert, maka variabel yang akan diukur dijabarkan menjadi

\footnotetext{
${ }^{10}$ Sugiyono. Metode Penelitian Kuanatitatif. Hal. 153

${ }^{11}$ Sugiyono.Metode Penelitian Kuanatitatif. Hal. 166
} 
indikator variabel. Kemudian indikator tersebut dijadikan sebagai titik tolak untuk menyusun item-item instrument yang dapat berupa pernyataan atau pertanyaan. ${ }^{12}$ Berikut kisi-kisi instrument penelitian yang disusun peneliti adalah sebagai berikut:

Tabel 2. Instrumen Penelitian

\begin{tabular}{cllc}
\hline No. & \multicolumn{1}{c}{ Variabel } & \multicolumn{1}{c}{ Indikator Variabel } & Nomor Item \\
\hline 1. & Pemanfaatan Internet & a. Kemudahan berkomunikasi & 1,2 \\
& (Variabel X) & b. Dukungan pembelajaran & 3,4 \\
& & c. Penghematan biaya & 5,6 \\
& & d. Penghilang kendala waktu & 7,8 \\
\multirow{2}{*}{ Minat Kunjung } & e. Peningkatan layanan & 9,10 \\
& (Variabel Y) & a. Kondisi fisik & $1,2,3$ \\
& & b. Keadaan psikis & $4,5,6$ \\
& & c. Lingkungan sosial & $7,8,9,10$ \\
\hline
\end{tabular}

\section{Analisis Data}

\section{a. Analisis Data Deskriptif}

Data yang sudah terkumpul melalui angket kemudian dianalisis. Analisis data dilakukan dengan menggunakan metode deskriptif dengan cara menyusun dan mengelompokkan data kemudian dianalisis. Data akan ditabulasi sesuai dengan kelompok aspek yang diteliti, untuk memudahkan interprestasi data yang disajikan dalam bentuk tabel kemudian dianalisis dan diinterprestasikan. Untuk menghitung presentasi hasil angket adalah: ${ }^{13}$

$$
P=\frac{F}{n} \times 100 \%
$$

Keterangan:

$\mathrm{P}=$ Presentase

$\mathrm{F}=$ Jumlah jawaban yang diperoleh

$\mathrm{n}=$ Jumlah responden $^{14}$

Setelah didapatkan presentase jawaban responden selanjutnya diberikan penafsiran atau penilaian terhadap hasil penelitian. Untuk menentukan kategori hasil presentase maka perlu adanya kriteria penilaian. Kriteria penilaian didapatkan dari skala interval, skala yang menunjukkan jarak antara satu data dengan data yang lain dan mempunyai bobot yang sama. Skala interval diperlukan untuk menempatkan posisi responden dalam suatu objek penilaian apakah termasuk dalam kriteria sangat baik, baik, tidak baik dan sangat tidak baik. Untuk menentukan skala interval yaitu:

\footnotetext{
${ }^{12}$ Sugiyono. Metode Penelitian Kuanatitatif. Hal. 152

${ }^{13}$ Syofian Siregar. Metode Penelitian Kuantitatif. Hal. 226

${ }^{14}$ Syofian Siregar. Metode Penelitian Kuantitatif. Hal. 126
} 
1. Jumlah komulatif terbesar $=99 \times 4=396$

Presentase skor yang diperoleh $=\frac{396 \times 100}{396}=100 \%$

2. Jumlah komulatif terkecil $=99 \times 1=99$

Presentase skor yang diperoleh $=\frac{99 \times 100}{396}=25 \%$

Nilai rentangnya adalah $100 \%-25 \%=75 \%$. Jika nilai rentang dibagi 4 skala pengukuran maka akan didapat nilai interval $=18,75 \%$ yang dieroleh dari $75 \%: 4$.

Tabel 3 Kriteria Penilaian

\begin{tabular}{|c|c|c|}
\hline NO & $\begin{array}{c}\text { PRESENTASE BATAS } \\
\text { INTERVAL }\end{array}$ & KATEGORI \\
\hline 1 & $81,25 \%-100,00 \%$ & Sangat Baik \\
\hline 2 & $62,50 \%-81,24 \%$ & Baik \\
\hline 3 & $43,75 \%-62,49 \%$ & Tidak Baik \\
\hline 4 & $25,00 \%-43,74 \%$ & Sangat Tidak Baik \\
\hline
\end{tabular}

\section{b. Regresi Linier Sederhana}

Salah satu alat yang dapat digunakan dalam memprediksi permintaan di masa akan datang berdasarkan data masa lalu atau untuk mengetahui pengaruh satu variabel bebas (independen) terhadap satu variabel terikat (dependen) adalah menggunakan regresi linier. Regresi linier sederhana hanya digunakan untuk satu variabel bebas dan satu variabel terikat. Tujuannya untuk meramalkan atau memprediksi besaran nilai variabel terikat yang di pengaruhi oleh variabel bebas. ${ }^{15}$ Rumus regresi linier sederhana:

$$
\mathrm{Y}=\mathrm{a}+\mathrm{b} \cdot \mathrm{X}
$$

Keterangan:

Y : variabel terikat

$\mathrm{X}$ : variabel bebas

$a=$ nilai konstanta harga $\mathrm{Y}$ jika $\mathrm{X}=0$

$b=$ nilai arah sebagai penentu ramalan (prediksi) yang nilai peningkatan $(+)$ atau nilai penurunan (-) variabel $\mathrm{Y}^{16}$

\section{Uji Hipotesis}

Pengujian hipotesis digunakan untuk menguji hipotesis yang telah disusun. Pengujian hipotesis dalam penelitian ini digunakan uji nilai signifikan pada analisis regresi. Pengujian hipotesis dalam pengujian ini digunakan untuk mengetahui pengaruh antara variabel X (manfaat internet) terhadap variabel Y (minat kunjung). ${ }^{17}$ Hipotesis yang

\footnotetext{
${ }^{15}$ Syofian Siregar. Metode Penelitian Kuantitatif. Hal. 284

${ }^{16}$ Sugiyono.Metode Penelitian Kuanatitatif. Hal. 279

${ }^{17}$ Sugiyono.Metode Penelitian Kuanatitatif. Hal. 38
} 
menunjukkan hubungan sederhana sehingga diuji dengan menggunakan teknik korelasi Product Moment. Uji signifikansi korelasi Product Moment dilakukan dengan membandingkan antara $r$ hitung dengan $r$ tabel pada taraf signifikansi 10\%. Apabila $r$ hitung lebih besar dari $r$ tabel maka hipotesis diterima. Sebaliknya, apabila $r$ hitung lebih kecil dari $r$ tabel maka hipotesis ditolak.

\section{Koefisien Determinasi}

Determinasi atau koefisien penentu adalah angka atau indeks yang digunakan untuk mengetahui besarnya sumbangan sebuah variabel (varibel bebas) terhadap variasi naik/turunnya variabel yang lain (variabel terikat). Koefisien determinasi menunjukkan presentase perubahan nilai dependen variabel yang disebabkan oleh perubahan nilai independen variabel. Untuk menghitung koefisien determinasi dapat dilakukan dengan rumus: ${ }^{18}$

$$
\mathrm{KD}=\mathrm{r}^{2} \times 100 \%
$$

Keterangan:

KD $\quad$ koefisien determinasi

$\mathrm{r}^{2} \quad$ : nilai koefisien korelasi

\section{HASIL DAN PEMBAHASAN}

\section{Analisis Deskriptif Varibel $X$ (Pemanfaatan Internet)}

a. Indikator Kemudahan Berkomunikasi

1) Internet di perpustakaan mempermudah dalam mengirim informasi

Tabel 4. Internet di perpustakaan mempermudah dalam mengirim informasi

\begin{tabular}{lcccc}
\hline \multicolumn{1}{c}{ JAWABAN } & $\begin{array}{c}\text { BOBOT } \\
\text { NILAI }\end{array}$ & F & P & S \\
\hline Sangat Setuju & 4 & 34 & $34,3 \%$ & 136 \\
Setuju & 3 & 53 & $53,5 \%$ & 159 \\
Tidak Setuju & 2 & 12 & $12,1 \%$ & 24 \\
Sangat Tidak Setuju & 1 & 0 & $0 \%$ & 0 \\
$\quad$ Jumlah & & 99 & $100 \%$ & 319 \\
\multicolumn{1}{c}{ Presentase Skor } & & $\mathrm{P}=(319 / 396) \times 100 \%=80,5 \%$ \\
\hline
\end{tabular}

Tabel di atas menjelaskan hasil dari pernyataan pertama responden menjawab sangat setuju sebanyak 34 orang dengan presentase 34,3\%, setuju sebanyak 53 orang dengan presentase setengah yaitu 53,5\%, tidak setuju sebanyak 12 orang dengan presentase $12,1 \%$ dan tidak ada responden yang menjawab sangat tidak

\footnotetext{
${ }^{18}$ Sugiyono. Metode Penelitian Kuanatitatif. Hlm. 251
} 
setuju dengan presentase $0 \%$. Maka hasil presentase skor yang diperoleh yaitu $\mathbf{8 0 , 5 \%}$ berada di interval 62,50\%-81,24\% dengan kategori penilaian baik.

2) Internet di perpustakaan membantu berkomunikasi dengan teman

Tabel 5. Internet di perpustakaan membantu berkomunikasi dengan teman

\begin{tabular}{lcccc}
\hline \multicolumn{1}{c}{ JAWABAN } & $\begin{array}{c}\text { BOBOT } \\
\text { NILAI }\end{array}$ & F & P & S \\
\hline Sangat Setuju & 4 & 23 & $23,2 \%$ & 92 \\
Setuju & 3 & 63 & $63,6 \%$ & 189 \\
Tidak Setuju & 2 & 13 & $13,1 \%$ & 26 \\
Sangat Tidak Setuju & 1 & 0 & $0 \%$ & 0 \\
\multicolumn{1}{c}{$\quad$ Jumlah } & & 99 & $100 \%$ & 307 \\
\hline
\end{tabular}

Tabel di atas menjelaskan jawaban responden paling banyak setuju sebanyak 63 orang dengan presentase $63,6 \%$, menjawab sangat setuju 23 orang dengan presentase $23,2 \%$, menjawab tidak setuju 13 orang dengan presentase $13,1 \%$ dan tidak ada yang menjawab sangat tidak setuju. Dengan demikian diperoleh presentase skor $\mathbf{7 7 , 5 \%}$ yang berada di interval $62,50 \%-81,24 \%$ dengan kategori baik.

3) Presentase rata-rata untuk Indikator Kemudahan Berkomunikasi

Tabel 6. Indikator Kemudahan Berkomunikasi

\begin{tabular}{clcc}
\hline NO & \multicolumn{1}{c}{ PERNYATAAN } & JAWABAN & $\begin{array}{c}\text { PRESENTASE } \\
\text { SKOR }\end{array}$ \\
\hline $\mathbf{1}$ & $\begin{array}{l}\text { Internet di perpustakaan mempermudah } \\
\text { dalam mengirim informasi }\end{array}$ & Baik & $80,5 \%$ \\
$\mathbf{2}$ & $\begin{array}{l}\text { Internet di perpustakaan membantu } \\
\text { berkomunikasi dengan teman }\end{array}$ & Baik & $77,5 \%$
\end{tabular}

Dari uraian di atas dapat dikatakan bahwa pada indikator kemudahan berkomunikasi jawaban yang didapatkan dari responden untuk pemanfaatan internet adalah Baik. Hal ini terlihat dari pertanyaan pertama memperoleh presentase skor $80,5 \%$ dan pertanyaan kedua $77,5 \%$. Dengan demikian presentase rata-rata pada indikator ini adalah 79\% yang berada di interval $62,50 \%-81,24 \%$. Dari hasil tersebut dapat disimpulkan bahwa dari jawaban responden berada pada kategori baik.

b. Dukungan pembelajaran

1) Internet di perpustakaan dapat digunakan untuk sarana pendidikan dan pembelajaran

Table 7. Internet di perpustakaan dapat digunakan untuk sarana pendidikan dan pembelajaran

\begin{tabular}{lcccc}
\multicolumn{1}{c}{ JAWABAN } & $\begin{array}{c}\text { BOBOT } \\
\text { NILAI }\end{array}$ & F & P & S \\
\hline Sangat Setuju & 4 & 43 & $43,4 \%$ & 172 \\
Setuju & 3 & 48 & $48,5 \%$ & 144 \\
\hline
\end{tabular}




\begin{tabular}{ccccc}
\hline Tidak Setuju & 2 & 8 & $8,1 \%$ & 16 \\
Sangat Tidak Setuju & 1 & 0 & $0 \%$ & 0 \\
$\quad$ Jumlah & & 99 & $100 \%$ & 332 \\
Presentase Skor & & $\mathrm{P}=(332 / 396) \times 100 \%=83,8 \%$ \\
\hline
\end{tabular}

Dari tabel di atas, tidak ada responden yang menjawab sangat tidak setuju, jawaban tidak setuju berjumlah 8 orang dengan presentase $8,1 \%$, jawaban setuju sebanyak 48 orang dengan presentase $48,5 \%$ dan yang menjawab sangat setuju sebanyak 43 orang dengan presentase 43,4\%. Dari hasil tersebut diperoleh presentase skor $83,8 \%$ yang berada di interval $81,25 \%-100 \%$ kategori sangat baik.

2) Internet di perpustakaan dapat digunakan untuk menambah wawasan serta ilmu pengetahuan

Table 8. Internet di perpustakaan dapat digunakan untuk menambah wawasan serta ilmu pengetahuan

\begin{tabular}{lcccc}
\multicolumn{1}{c}{ JAWABAN } & $\begin{array}{c}\text { BOBOT } \\
\text { NILAI }\end{array}$ & F & P & S \\
\hline Sangat Setuju & 4 & 42 & $42,4 \%$ & 168 \\
Setuju & 3 & 47 & $47,5 \%$ & 141 \\
Tidak Setuju & 2 & 9 & $9,1 \%$ & 18 \\
Sangat Tidak Setuju & 1 & 1 & $1 \%$ & 1 \\
$\quad$ Jumlah & & 99 & $100 \%$ & 328 \\
\multicolumn{1}{c}{ Presentase Skor } & & P=(328/396) x $100 \%=82,8 \%$ \\
\hline
\end{tabular}

Tabel di atas merupakan jawaban responden yang menjawab sangat setuju sebanyak 42 orang dengan presentase $42,4 \%$, yang menjawab setuju sebanyak 47 orang dengan presentase $47,5 \%$, yang menjawab tidak setuju sebanyak 9 orang dan yang menjawab sangat tidak setuju hanya 1 orang dengan presentase $1 \%$. Dari hasil tersebut maka diperoleh presentase skor sebanyak $\mathbf{8 2 , 8 \%}$ pada interval 81,25\%-100\% dengan kategori sangat baik.

3) Presentase rata-rata untuk indikator dukungan pembelajaran

Tabel 9. Indikator Dukungan Pembelajaran

\begin{tabular}{cccc}
\hline NO & PERNYATAAN & JAWABAN & $\begin{array}{c}\text { PRESENTASE } \\
\text { SKOR }\end{array}$ \\
\hline $\mathbf{1}$ & Internet di perpustakaan dapat digunakan & Sangat Baik & $83,8 \%$ \\
$\mathbf{2}$ & $\begin{array}{c}\text { untuk sarana pendidikan dan pembelajaran } \\
\text { Internet di perpustakaan dapat digunakan } \\
\text { untuk menambah wawasan serta ilmu } \\
\text { pengetahuan } \\
\end{array}$ & Sangat Baik & $82,8 \%$ \\
& & & \\
& Presentase Rata-rata & & $83,3 \%$ \\
\hline
\end{tabular}

Tabel di atas menjelaskan jawaban responden untuk pernyataan pertama dengan presentase skor $83,8 \%$ dan pernyataan kedua dengan presentase skor $82,8 \%$, 
kedua pernyataan tersebut berada pada interval yang sama dengan kategori sangat tinggi. Dengan demikian dapat dikatakan bahwa pada indikator dukungan pembelajaran hasil presentase rata-rata adalah $\mathbf{8 3 , 3 \%}$ yang berada di interval 81,25\%-100\% dengan kategori sangat baik.

c. Penghematan biaya

1) Internet dapat menghemat paket data android pemustaka

Table 10. Internet dapat menghemat paket data android pemustaka

\begin{tabular}{lcccc}
\multicolumn{1}{c}{ JAWABAN } & $\begin{array}{c}\text { BOBOT } \\
\text { NILAI }\end{array}$ & F & P & S \\
\hline Sangat Setuju & 4 & 46 & $46,5 \%$ & 184 \\
Setuju & 3 & 43 & $43,4 \%$ & 129 \\
Tidak Setuju & 2 & 8 & $8,1 \%$ & 16 \\
Sangat Tidak Setuju & 1 & 2 & $2 \%$ & 2 \\
$\quad$ Jumlah & & 99 & $100 \%$ & 331 \\
\hline
\end{tabular}

Presentase Skor

Tabel di atas didapat bahwa responden menjawab sangat tidak setuju sebanyak 2 orang dengan presentase $2 \%$, responden yang menjawab tidak setuju sebanyak 8 orang dengan presentase $8,1 \%$, responden menjawab setuju sebanyak 43 orang dengan presentase $43,4 \%$ dan yang menjawab sangat setuju sebanyak 46 orang dengan presentase $46,5 \%$. Dengan demikian maka presentase skor diperoleh adalah $\mathbf{8 3 , 6 \%}$ berada di interval $81,25 \%-100 \%$ kategori sangat baik.

2) Dengan menggunakan internet di perpustakaan, pemustaka merasa puas dalam mengakses internet

Tabel 11. dengan menggunakan internet di perpustakaan, pemustaka merasa puas dalam mengakses internet

\begin{tabular}{lcccc}
\hline \multicolumn{1}{c}{ JAWABAN } & $\begin{array}{c}\text { BOBOT } \\
\text { NILAI }\end{array}$ & F & P & S \\
\hline Sangat Setuju & 4 & 31 & $31,3 \%$ & 124 \\
Setuju & 3 & 52 & $52,5 \%$ & 156 \\
Tidak Setuju & 2 & 16 & $16,2 \%$ & 32 \\
Sangat Tidak Setuju & 1 & 0 & $0 \%$ & 0 \\
$\quad$ Jumlah & & 99 & $100 \%$ & 312 \\
\multicolumn{1}{c}{ Presentase Skor } & & P=(312/396) x $100 \%=78,8 \%$ \\
\hline
\end{tabular}

Tabel di atas hasil untuk pernyataan keenam, dengan menggunakan internet di perpustakaan, pemustaka merasa puas dalam mengakses internet untuk indikator ketiga. Maka jawaban responden untuk sangat setuju sebanyak 31 orang dengan presentase $31,3 \%$, yang menjawab setuju sebanyak 52 orang dengan presentase $52,5 \%$, yang menjawab tidak setuju sebanyak 16 orang dengan presentase $16,2 \%$ dan tidak ada yang menjawab sangat tidak setuju. Pada pernyataan ini memperoleh presentase skor $\mathbf{7 8 , 8 \%}$ berada di interval $62,50 \%-81,24 \%$ dengan kategori baik. 
3) Presentase rata-rata indikator penghematan biaya

Tabel 12. Indikator Penghematan Biaya

\begin{tabular}{clcc}
\hline NO & \multicolumn{1}{c}{ PERNYATAAN } & JAWABAN & $\begin{array}{c}\text { PRESENTASE } \\
\text { SKOR }\end{array}$ \\
\hline $\mathbf{1}$ & $\begin{array}{l}\text { Internet dapat menghemat paket data } \\
\text { android pemustaka }\end{array}$ & Sangat Baik & $83,6 \%$ \\
$\mathbf{2}$ & $\begin{array}{l}\text { Dengan menggunakan internet di } \\
\text { perpustakaan, pemustaka merasa puas } \\
\text { dalam mengakses internet } \\
\text { Presentase Rata-rata }\end{array}$ & Baik & $78,8 \%$ \\
\hline
\end{tabular}

Tabel di atas merupakan hasil untuk indikator penghematan biaya yang mana pada pernyataan pertama hasil yang didapatkan adalah 83,6\% dengan kategori sangat baik sedangkan untuk pernyataan kedua presentasenya 78,8\% dengan kategori baik. Dari hasil tersebut dapat disimpulkan bahwa presentase rata-rata yaitu $\mathbf{8 1 , 2 \%}$ berada di interval $81,25 \%-100 \%$. Jadi, untuk indikator penghematan biaya dengan kategori baik.

d. Penghilang kendala waktu

1) Internet mempermudah dalam pengembalian buku di perpustakaan

Tabel 13. Internet mempermudah dalam pengembalian buku di perpustakaan

\begin{tabular}{lcccc}
\hline \multicolumn{1}{c}{ JAWABAN } & $\begin{array}{c}\text { BOBOT } \\
\text { NILAI }\end{array}$ & F & P & S \\
\hline Sangat Setuju & 4 & 32 & $32,3 \%$ & 128 \\
Setuju & 3 & 54 & $54,5 \%$ & 162 \\
Tidak Setuju & 2 & 12 & $12,1 \%$ & 24 \\
Sangat Tidak Setuju & 1 & 1 & $1 \%$ & 1 \\
\multicolumn{1}{c}{ Jumlah } & & 99 & $100 \%$ & 315 \\
& Prsentase Skor & & P=(315/396) x $100 \%=79,5 \%$ \\
\hline
\end{tabular}

Hasil dari tabel di atas bahwa responden menjawab paling sedikit sangat tidak setuju sebanyak 1 orang dengan presentase $1 \%$, yang paling banyak yaitu jawaban setuju 54 orang dengan presentase 54,5\%, yang menjawab sangat setuju 32 orang dengan presentase $32,3 \%$ dan yang menjawab tidak setuju sebanyak 12 orang dengan presentase $12,1 \%$. Dari uraian di atas maka presentase skor yang diperoleh adalah $\mathbf{7 9 , 5 \%}$ berada di interval 62,50\%-81,24\% kategori baik.

2) Internet mempercepat dalam pengisian absen pemustaka

Tabel 14. Internet mempercepat dalam pengisian absen pemustaka 


\begin{tabular}{lcccc}
\hline \multicolumn{1}{c}{ JAWABAN } & $\begin{array}{c}\text { BOBOT } \\
\text { NILAI }\end{array}$ & F & P & S \\
\hline Sangat Setuju & 4 & 40 & $40,4 \%$ & 160 \\
Setuju & 3 & 52 & $52,5 \%$ & 156 \\
Tidak Setuju & 2 & 6 & $6,1 \%$ & 12 \\
Sangat Tidak Setuju $\quad$ Jumlah & 1 & 1 & $1 \%$ & 1 \\
\multicolumn{1}{c}{ Presentase Skor } & & 99 & $100 \%$ & 329 \\
\hline
\end{tabular}

Pernyataan kedelapan responden lebih banyak memilih setuju yaitu sebanyak 52 orang dengan presentase $52,5 \%$, yang menjawab sangat setuju sebanyak 40 orang dengan presentase $40,4 \%$, tidak setuju sebanyak 6 orangn dengan presentase $6,1 \%$ dan 1 orang menjawab sangat tidak setuju dengan presentase $1 \%$. Maka presentase skor untuk pernyataan kedelapan yaitu $\mathbf{8 3 , 1 \%}$ berada di interval 81,25\%-100\% kategori sangat baik.

3) Presentase rata-rata indikator penghilang kendala waktu

Tabel 15. Indikator penghilang kendala waktu

\begin{tabular}{clcc}
\hline NO & \multicolumn{1}{c}{ PERNYATAAN } & JAWABAN & $\begin{array}{c}\text { PRESENTASE } \\
\text { SKOR }\end{array}$ \\
\hline $\mathbf{1}$ & $\begin{array}{l}\text { Internet mempermudah dalam } \\
\text { pengembalian buku di } \\
\text { perpustakaan }\end{array}$ & Baik & $79,5 \%$ \\
$\mathbf{2}$ & $\begin{array}{l}\text { Internet mempercepat dalam } \\
\text { pengisian absen pemustaka } \\
\text { Presentase Rata-rata }\end{array}$ & Sangat Baik & $83,1 \%$ \\
\hline
\end{tabular}

Tabel di atas merupakan hasil untuk indikator penghilang kendala waktu diperoleh bahwa pernyataan pertama 79,5\% dengan kategori tinggi dan pernyatan ke dua $83,1 \%$ dengan kategori sangat tinggi. Dengan demikian dapat disimpulkan bahwa presentase rata-rata pada indikator penghilang kendala waktu adalah $\mathbf{8 1 , 3 \%}$. Jadi, penghilang kendala waktu dalam pemanfaatan internet dengan kategori sangat baik.

e. Peningkatan layanan

1) Internet membantu dalam pencarian koleksi melalui OPAC

Tabel 16. Internet membantu dalam pencarian koleksi melalui OPAC)

\begin{tabular}{lcccc}
\hline \multicolumn{1}{c}{ JAWABAN } & $\begin{array}{c}\text { BOBOT } \\
\text { NILAI }\end{array}$ & F & P & S \\
\hline Sangat Setuju & 4 & 43 & $43,4 \%$ & 172 \\
Setuju & 3 & 48 & $48,5 \%$ & 144 \\
Tidak Setuju & 2 & 8 & $8,1 \%$ & 16 \\
Sangat Tidak Setuju & 1 & 0 & $0 \%$ & 0 \\
\multicolumn{1}{c}{$\quad$ Jumlah } & & 99 & $100 \%$ & 328 \\
& & Presentase Skor & &
\end{tabular}

Tabel di atas menjelaskan responden tidak ada yang menjawab sangat tidak setuju dengan presentase $0 \%$, yang menjawab sangat setuju sebanyak 43 orang dengan presentase $43,4 \%$, yang menjawab setuju 48 orang dengan presentase $48,5 \%$ dan 
yang menjawab tidak setuju sebanyak 8 orang dengan presentase $8,1 \%$. Maka diperoleh presentase skor sebanyak $\mathbf{8 2 , 8 \%}$ yang berada di interval 81,25\%-100\% kategori sangat baik.

2) Internet digunakan untuk absen pemustaka

Tabel 17.Internet digunakan untuk absen pemustaka

\begin{tabular}{lcccc}
\hline \multicolumn{1}{c}{ JAWABAN } & $\begin{array}{c}\text { BOBOT } \\
\text { NILAI }\end{array}$ & F & P & S \\
\hline Sangat Setuju & 4 & 36 & $36,4 \%$ & 144 \\
Setuju & 3 & 56 & $56,6 \%$ & 168 \\
Tidak Setuju & 2 & 7 & $7,1 \%$ & 14 \\
Sangat Tidak Setuju & 1 & 0 & $0 \%$ & 0 \\
\multicolumn{1}{c}{ Jumlah } & & 99 & $100 \%$ & 326 \\
Presentase Skor & & P=(326/396) x 100\%=82,3\% \\
\hline
\end{tabular}

Pada pernyataan ini sebanyak 99 respoden tidak ada yang menjawab sangat setuju dan paling banyak banyak menjawab setuju sebanyak 56 orang dengan presentase $56,6 \%$, yang menjawab sangat setuju 36 orang dengan presentase 56,6\% sedangkan yang menjawab tidak setuju 7 orang dengan presentase $7,1 \%$. Maka presentase skor untuk pernyataan ini adalah $\mathbf{8 2 , 3 \%}$ berada di interval $81,25 \%$ 100\% dengan kategori sangat baik.

3) Presentase rata-rata indikator peningkatan layanan

Tabel 18. Indikator peningkatan layanan

\begin{tabular}{clcc}
\hline NO & \multicolumn{1}{c}{ PERNYATAAN } & JAWABAN & $\begin{array}{c}\text { PRESENTASE } \\
\text { SKOR }\end{array}$ \\
\hline $\mathbf{1}$ & $\begin{array}{l}\text { Internet membantu dalam } \\
\text { pencarian koleksi melalui OPAC }\end{array}$ & Sangat Tinggi & $82,8 \%$ \\
$\mathbf{2}$ & $\begin{array}{l}\text { Internet digunakan untuk absen } \\
\text { pemustaka }\end{array}$ & Sangat Tinggi & $82,3 \%$ \\
\hline Presentase Rata-rata & & $82,5 \%$ \\
\hline
\end{tabular}

Dari tabel di atas, pada pernyataan pertama diperoleh presentase skor $82,8 \%$ dan pernyataan kedua $82,3 \%$ dengan kategori kedua pertanyaan yaitu sangat tinggi. Dengan demikian, hasil presentase rata-rata untuk indikator ini adalah 82,5\%. Jadi, peningkatan layanan dengan kategori sangat baik.

\section{Analsis Deskriptif Variabel Y (Minat Kunjung)}

a. Kondisi fisik 
1) Perpustakaan menarik dengan adanya koleksi yang dibutuhkan dan penyediaan internet

Tabel 19. Perpustakaan menarik dengan adanya koleksi yang dibutuhkan dan penyediaan internet

\begin{tabular}{lcccc}
\hline \multicolumn{1}{c}{ JAWABAN } & $\begin{array}{c}\text { BOBOT } \\
\text { NILAI }\end{array}$ & F & P & S \\
\hline Sangat Setuju & 4 & 32 & $32,3 \%$ & 128 \\
Setuju & 3 & 59 & $59,6 \%$ & 177 \\
Tidak Setuju & 2 & 5 & $5,1 \%$ & 10 \\
Sangat Tidak Setuju & 1 & 3 & $3 \%$ & 3 \\
$\quad$ Jumlah & & 99 & $100 \%$ & 318 \\
\multicolumn{1}{c}{ Presentase Skor } & & $\mathrm{P}=(318 / 396) \times 100 \%=80,3 \%$ \\
\hline
\end{tabular}

Responden menjawab sangat setuju sebanyak 32 orang dengan presentase $32,3 \%$, yang menjawab setuju sebanyak 59 orang dengan presentase $59,6 \%$ dan yang menjawab sangat tidak setuju sebanyak 3 orang dengan presentase 3\%. Maka diperoleh presentase skor untuk pernyataan ini adalah $\mathbf{8 0 , 3 \%}$ yang berada pada interval 62,50\%-81,24\% dengan kategori baik.

2) Perpustakaan menyediakan ruang baca yang nyaman dengan koneksi internet yang cepat

Tabel 20. Perpustakaan menyediakan ruang baca yang nyaman dengan koneksi internet yang cepat

\begin{tabular}{lcccc}
\hline \multicolumn{1}{c}{ JAWABAN } & $\begin{array}{c}\text { BOBOT } \\
\text { NILAI }\end{array}$ & F & P & S \\
\hline Sangat Setuju & 4 & 36 & $36,4 \%$ & 144 \\
Setuju & 3 & 42 & $42,4 \%$ & 126 \\
Tidak Setuju & 2 & 19 & $19,2 \%$ & 38 \\
Sangat Tidak Setuju & 1 & 2 & $2 \%$ & 2 \\
\multicolumn{1}{c}{$\quad$ Jumlah } & & 99 & $100 \%$ & 310 \\
\hline
\end{tabular}

Responden menjawab sangat tidak setuju sebanyak 2 orang dengan presentase $2 \%$, responden yang menjawan tidak setuju sebanyak 19 orang dengan presentase $19,2 \%$, yang menjawab setuju sebanyak 42 orang dengan presentase $42,4 \%$ dan respoden yang menjawab sangat setuju sebanyak 36 orang dengan presentase 36,4\%. Dengan demikian maka presentase skor yang diperoleh adalah $\mathbf{7 8 , 3 \%}$ berada di interval 62,50\%-81,24\% dan berkategori baik.

3) Perpustakaan sebagai tempat belajar dan rekreasi dengan memanfaatkan internet

Tabel 20. Perpustakaan sebagai tempat belajat dan rekreasi dengan memanfaatkan internet

\begin{tabular}{lcccc}
\hline \multicolumn{1}{c}{ JAWABAN } & $\begin{array}{c}\text { BOBOT } \\
\text { NILAI }\end{array}$ & F & P & S \\
\hline Sangat Setuju & 4 & 29 & $29,3 \%$ & 116 \\
Setuju & 3 & 64 & $64,6 \%$ & 192 \\
Tidak Setuju & 2 & 4 & $4 \%$ & 8 \\
Sangat Tidak Setuju & 1 & 2 & $2 \%$ & 2 \\
$\quad$ Jumlah & & 99 & $100 \%$ & 318 \\
\hline
\end{tabular}




\begin{abstract}
Presentase Skor
$\mathrm{P}=(318 / 396) \times 100 \%=80,3 \%$

Jawaban yang diperoleh dari responden yaitu paling rendah untuk sangat tidak setuju sebanyak 2 orang dengan presentase $2 \%$, yang menjawab sangat setuju sebanyak 29 orang dengan presentase $29,3 \%$, yang menjawab setuju sebanyak 64 orang dengan presentase 64,6\% dan yang menjawab tidak setuju sebanyak 4 orang dengan presentase $4 \%$. Hasil hasil tersebut diperoleh presentase skor 80,3\% di interval 62,50\%-81,24\% kategori baik.
\end{abstract}

4) Presentase rata-rata indikator kondisi fisik

Tabel 21. Kondisi fisik

\begin{tabular}{clcc}
\hline NO & \multicolumn{1}{c}{ PERNYATAAN } & JAWABAN & $\begin{array}{c}\text { PRESENTASE } \\
\text { SKOR }\end{array}$ \\
\hline $\mathbf{1}$ & $\begin{array}{l}\text { Perpustakaan menarik dengan } \\
\text { adanya koleksi yang dibutuhkan } \\
\text { dan penyediaan internet }\end{array}$ & Baik & $80,3 \%$ \\
$\mathbf{2}$ & $\begin{array}{l}\text { Perpustakaan menyediakan } \\
\text { ruang baca yang nyaman } \\
\text { dengan koneksi internet yang } \\
\text { cepat }\end{array}$ & Baik & $78,3 \%$ \\
$\mathbf{3}$ & $\begin{array}{l}\text { Perpustakaan sebagai tempat } \\
\text { belajar dan rekreasi dengan } \\
\text { memanfaatkan internet } \\
\text { Presentase Rata-rata }\end{array}$ & Baik & $80,3 \%$ \\
\hline
\end{tabular}

Dari ketiga pernyataan di atas hasil yang didapatkan memiliki presentase skor 80,3\% untuk pernyataan pertama dan ketiga dengan kategori baik. Sedangkan pernyataan kedua memperoleh presentase 78,3\% dengan kategori baik. Dengan demikian, hasil presentase rata-rata yang didapatkan adalah $\mathbf{7 9 , 6 \%}$ pada interval 62,50\%-81,24\% Jadi, kondisi fisik dalam meningkatkan minat kunjung dengan kategori baik.

b. Keadaan psikis

1) Pemustaka merasa senang karena ruangan yang tertata rapi dilengkapi dengan fasilitas yang tersedia

Tabel 22. Pemustaka merasa senang karena ruangan yang tertata rapi dilengkapi dengan fasilitas yang tersedia

\begin{tabular}{lcccc}
\hline \multicolumn{1}{c}{ JAWABAN } & $\begin{array}{c}\text { BOBOT } \\
\text { NILAI }\end{array}$ & F & P & S \\
\hline Sangat Setuju & 4 & 37 & $37,4 \%$ & 148 \\
Setuju & 3 & 47 & $47,5 \%$ & 141 \\
Tidak Setuju & 2 & 11 & $11,1 \%$ & 22 \\
Sangat Tidak Setuju & 1 & 4 & $4 \%$ & 4 \\
\multicolumn{1}{c}{ Jumlah } & & 99 & $100 \%$ & 315 \\
Presentase Skor & & $\mathrm{P}=(315 / 396) \times 100 \%=79,5 \%$ \\
\hline
\end{tabular}


Tabel di atas responden menjawab sangat setuju sebanyak 37 orang dengan presentase $37,4 \%$, responden yang menjawab setuju sebanyak 47 orang dengan presentase setengah yaitu $47,5 \%$, responden yang menjawab tidak setujuk sebanyak 11 orang dengan presentase $11,1 \%$ dan responden yang menjawab sangat tidak setuju sebanyak $4 \%$ dengan presentase $4 \%$. Maka hasil presentase skor yang diperoleh untuk pernyataan ini yaitu 79,5\% pada skala $62,50 \%$ $81,24 \%$. Skala ini menunjukkan kategorinya adalah baik.

2) Koleksi di perpustakaan memenuhi kebutuhan informasi yang dibutuhkan

Tabel 23. Koleksi di perpustakaan memenuhi kebutuhan informasi yang dibutuhkan

\begin{tabular}{lcccc}
\hline \multicolumn{1}{c}{ JAWABAN } & $\begin{array}{c}\text { BOBOT } \\
\text { NILAI }\end{array}$ & F & P & S \\
\hline Sangat Setuju & 4 & 23 & $23,2 \%$ & 92 \\
Setuju & 3 & 58 & $58,6 \%$ & 174 \\
Tidak Setuju & 2 & 16 & $16,2 \%$ & 32 \\
Sangat Tidak Setuju & 1 & 2 & $2 \%$ & 2 \\
$\quad$ Jumlah & & 99 & $100 \%$ & 300 \\
\multicolumn{1}{c}{ Presentase Skor } & & P=(300/396) x $100 \%=75,8 \%$ \\
\hline
\end{tabular}

Responden lebih banyak memilih setuju yaitu sebanyak 58 orang dengan presentase 58,6\%, kemudian yang menjawab sangat setuju sebanyak 23 orang dengan presentase $23,2 \%$, yang menjawab tidak setuju sebanyak 16 orang dengan presentase $16,2 \%$ dan 2 orang menjawab sangat tidak setuju dengan presentase $2 \%$. Maka presentase skor untuk pernyataan ini yaitu $\mathbf{7 5 , 8 \%}$ berada di interval 62,50\%-81,24\% kategori baik

3) Pemustaka menemukan pengalaman baru setelah berkunjung

Tabel 24. Pemustaka menemukan pengalaman baru setelah berkunjung

\begin{tabular}{lcccc}
\hline \multicolumn{1}{c}{ JAWABAN } & $\begin{array}{c}\text { BOBOT } \\
\text { NILAI }\end{array}$ & F & P & S \\
\hline Sangat Setuju & 4 & 27 & $27,3 \%$ & 108 \\
Setuju & 3 & 64 & $64,6 \%$ & 192 \\
Tidak Setuju & 2 & 6 & $6,1 \%$ & 12 \\
Sangat Tidak Setuju & 1 & 2 & $2 \%$ & 2 \\
$\quad$ Jumlah & & 99 & $100 \%$ & 314 \\
\multicolumn{1}{c}{ Presentase Skor } & & P=(314/396) x 100\%=79,3\% \\
\hline
\end{tabular}

Hasil yang diperoleh bahwa responden hanya 2 orang yang menjawab sangat tidak setuju dengan presentase $2 \%$, yang menjawab tidak setuju sebanyak 6 orang dengan presentase $6,1 \%$, yang menjawab sangat setuju sebanyak 27 orang dengan presentase $27,3 \%$ dan paling banyak menjawab setuju sebanyak 64 orang dengan presentase $64,6 \%$. Untuk hasil presentase skor diperoleh $\mathbf{7 9 , 3 \%}$ berada di interval 62,50\%-81,24\% dengan persepsi ini baik.

4) Presentase rata-rata indikator keadaan psikis 
Tabel 25. Indikator keadaan psikis

\begin{tabular}{|c|c|c|c|}
\hline $\mathrm{NO}$ & PERNYATAAN & JAWABAN & $\begin{array}{c}\text { PRESENTASE } \\
\text { SKOR }\end{array}$ \\
\hline 1 & $\begin{array}{l}\text { Pemustaka merasa senang } \\
\text { karena ruangan yang tertata rapi } \\
\text { dilengkapi dengan fasilitas yang } \\
\text { tersedia }\end{array}$ & Baik & $79,5 \%$ \\
\hline 2 & $\begin{array}{l}\text { Koleksi di perpustakaan } \\
\text { memenuhi kebutuhan informasi } \\
\text { yang dibutuhkan }\end{array}$ & Baik & $75,8 \%$ \\
\hline 3 & $\begin{array}{l}\text { Pemustaka menemukan } \\
\text { pengalaman baru setelah } \\
\text { berkunjung }\end{array}$ & Baik & $79,3 \%$ \\
\hline & Presentase Rata-rata & & $78,2 \%$ \\
\hline
\end{tabular}

Tabel di atas untuk indikator keadaan psikis hasil yang didapatkan dari tiga pernyataan yaitu pernyataan pertama presentase skor yang didapatkan 79,5\%, pernyataan kedua memperoleh presentase skor 75,8 sedangakan pernyataan ketiga presentase skor yang didapatkan $78,2 \%$. Ketiga pernyataan tersebut berada di interval $62,50 \%-81,24 \%$. Jumlah presentase rata-rata indikator kedua yaitu $\mathbf{7 8 , 2} \%$. Dengan demikian indikator keadaan psikis dalam meningkatkan minat kunjung dengan kategori baik.

c. Lingkungan sosial

1) Pustakawan memberi layanan yang baik kepada pemustaka untuk mengakses internet

Tabel 26. Pustakawan memberi layanan yang baik kepada pemustaka untuk mengakses internet

\begin{tabular}{|c|c|c|c|c|}
\hline JAWABAN & $\begin{array}{c}\text { BOBOT } \\
\text { NILAI }\end{array}$ & $\mathrm{F}$ & $\mathrm{P}$ & $\mathrm{S}$ \\
\hline Sangat Setuju & 4 & 29 & $29,3 \%$ & 116 \\
\hline Setuju & 3 & 58 & $58,6 \%$ & 174 \\
\hline Tidak Setuju & 2 & 10 & $10,1 \%$ & 20 \\
\hline Sangat Tidak Setuju & 1 & 2 & $2 \%$ & 2 \\
\hline Jumlah & & 99 & $100 \%$ & 319 \\
\hline
\end{tabular}

Responden menjawab setuju sebanyak 58 orang dengan presentase $58,6 \%$, sangat setuju 29 orang dengan presentase $29,3 \%$, tidak setuju 10 orang dengan presentase $10,1 \%$, dan 2 orang menjawab sangat tidak setuju dengan presentase $2 \%$. Dengan demikian diperoleh presentase skor $\mathbf{8 0 , 5 \%}$ yang berada di interval 62,50\%-81,24\% dengan kategori baik.

2) Pemustaka termotivasi ke perpustakaan karena ajakan teman

Tabel 27. Pemustaka termotivasi ke perpustakaan karena ajakan teman

\begin{tabular}{lcccc}
\multicolumn{1}{c}{ JAWABAN } & $\begin{array}{c}\text { BOBOT } \\
\text { NILAI }\end{array}$ & F & P & S \\
\hline Sangat Setuju & 4 & 31 & $31,3 \%$ & 124 \\
Setuju & 3 & 61 & $61,6 \%$ & 183 \\
Tidak Setuju & 2 & 5 & $5,1 \%$ & 10 \\
\hline
\end{tabular}




\begin{tabular}{ccccc}
\hline Sangat Tidak Setuju & 1 & 2 & $2 \%$ & 2 \\
Jumlah & & 99 & $100 \%$ & 319 \\
Presentase Skor & & $\mathrm{P}=(319 / 396) \times 100 \%=80,5 \%$ \\
\hline
\end{tabular}

Jawaban responden untuk sangat setuju sebanyak 31 orang dengan presentase $31,3 \%$, setuju sebanyak 61 orang dengan presentase $61,6 \%$, tidak setuju sebanyak 5 orang dengan presentase $5,1 \%$ dan 2 orang menjawab sangat tidak setuju dengan presentase $2 \%$. Pada pernyataan ini memperoleh presentase skor $\mathbf{8 0 , 5 \%}$ berada di interval 62,50\%-81,24\% dengan kategori baik.

3) Pustakawan membantu pemustaka dalam mencari informasi yang dibutuhkan

Tabel 28. Pustakawan membantu pemustaka dalam mencari informasi yang dibutuhkan

\begin{tabular}{lcccc}
\hline \multicolumn{1}{c}{ JAWABAN } & $\begin{array}{c}\text { BOBOT } \\
\text { NILAI }\end{array}$ & F & P & S \\
\hline Sangat Setuju & 4 & 44 & $44,4 \%$ & 176 \\
Setuju & 3 & 51 & $51,5 \%$ & 153 \\
Tidak Setuju & 2 & 3 & $3 \%$ & 6 \\
Sangat Tidak Setuju & 1 & 1 & $1 \%$ & 1 \\
$\quad$ Jumlah & & 99 & $100 \%$ & 332 \\
\multicolumn{1}{c}{ Presentase Skor } & & $\mathrm{P}=(332 / 396) \times 100 \%=83,8 \%$ \\
\hline
\end{tabular}

Pada pernyataan ini sebanyak 99 respoden hanya 1 orang yang menjawab sangat setuju dengan presentase $1 \%$, setuju sebanyak 51 orang dengan presentase $51,5 \%$, sangat setuju 44 orang dengan presentase $44,4 \%$ sedangkan jawaban tidak setuju 3 orang dengan presentase $3 \%$. Maka presentase skor untuk pernyataan ini adalah $\mathbf{8 3 , 8 \%}$ berada di interval $81,25 \%-100 \%$ dengan kategori sangat baik.

4) Pustakawan memberi layanan yang cepat dan tepat kepada pemustaka

Tabel 29. Pustakawan memberi layanan yang cepat dan tepat kepada pemustaka

\begin{tabular}{lcccc}
\multicolumn{1}{c}{ JAWABAN } & $\begin{array}{c}\text { BOBOT } \\
\text { NILAI }\end{array}$ & F & P & S \\
\hline Sangat Setuju & 4 & 24 & $24,2 \%$ & 96 \\
Setuju & 3 & 49 & $49,5 \%$ & 147 \\
Tidak Setuju & 2 & 23 & $23,2 \%$ & 46 \\
Sangat Tidak Setuju & 1 & 3 & $3 \%$ & 3 \\
$\quad$ Jumlah & & 99 & $100 \%$ & 292
\end{tabular}

Presentase Skor $\mathrm{P}=(292 / 396) \times 100 \%=73,7 \%$

Hasil jawaban responden paling rendah sangat tidak setuju 3 orang dengan presentase $3 \%$. Kemudian jawaban responden paling banyak di jawaban setuju yaitu 49 orang dengan presentase $49,5 \%$, sangat setuju 24 orang dengan presentase $24,2 \%$ dan jawaban tidak setuju benyak 23 orang dengan presentase 23,2\%. Pada tabel di atas, maka presentase skor untuk pernyataan ini yaitu $\mathbf{7 3 , 7 \%}$ berada di interval 62,50\%-81,24\% dengan kategori baik. 
5) Presentase rata-rata indikator lingkungan sosial

Tabel 30. Indikator lingkungan sosial

\begin{tabular}{|c|c|c|c|}
\hline $\mathrm{NO}$ & PERNYATAAN & JAWABAN & $\begin{array}{c}\text { PRESENTASE } \\
\text { SKOR }\end{array}$ \\
\hline 1 & $\begin{array}{l}\text { Pustakawan memberi layanan } \\
\text { yang baik kepada pemustaka } \\
\text { untuk mengakses internet }\end{array}$ & Baik & $80,5 \%$ \\
\hline 2 & $\begin{array}{l}\text { Pemustaka termotivasi ke } \\
\text { perpustakaan karena ajakan } \\
\text { teman }\end{array}$ & Baik & $80,5 \%$ \\
\hline 3 & $\begin{array}{l}\text { Pustakawan membantu } \\
\text { pemustaka dalam mencari } \\
\text { informasi yang dibutuhkan }\end{array}$ & Sangat Baik & $83,8 \%$ \\
\hline \multirow[t]{2}{*}{4} & $\begin{array}{l}\text { Pustakawan memberi layanan } \\
\text { yang cepat dan tepat kepada } \\
\text { pemustaka }\end{array}$ & Baik & $73,7 \%$ \\
\hline & Presentase Rata-rata & & $79,6 \%$ \\
\hline
\end{tabular}

Dari pernyataan pertama dan kedua diperoleh presentase skor $80,5 \%$ dengan kategori baik, pernyataan ketiga memperoleh presentase skor 83,8\% dan pernyataan keempat memperoleh presentase skor 73,7\% dengan kategori baik. Dengan demikian, kesimpulan dari tabel di atas presentase rata-rata indikator lingkungan sosial adalah $\mathbf{7 9 , 6 \%}$ berada pada interval 62,50\%-81,24\%. Jadi, indikator lingkungan sosial dalam meningkatkan minat kunjung dengan kategori baik.

\section{Uji Regresi Linier Sederhana}

Untuk uji regresi linier sederhana ini peneliti menggunakan aplikasi SPSS, adapun hasilnya sebagai berikut:

Tabel 31. Koefisien Regresi Sederhana

$\left(\left(\right.\right.$ Coefficients $\left.^{\mathrm{a}}\right)$

\begin{tabular}{|l|r|r|r|r|r|}
\hline Model & \multicolumn{2}{|l|}{ Unstandardized Coefficients } & \multicolumn{1}{|c|}{$\begin{array}{c}\text { Standardized } \\
\text { Coefficients }\end{array}$} & \multirow{2}{*}{ Sig. } \\
\cline { 2 - 4 } & \multicolumn{1}{|c|}{$\mathrm{B}$} & Std. Error & \multicolumn{1}{|c|}{ Beta } & & \\
\hline (Constant) & 14.402 & 3.212 & & 4.484 & .000 \\
Manfaat Internet & .527 & .098 & .481 & 5.405 & .000 \\
\hline
\end{tabular}

$\mathrm{a}=$ angka konstanta dari unstandardized coefficients. Dalam kasus ini nilainya sebesar 14.402..

$\mathrm{b}=$ angka koefisien regresi. Nilainya sebesar 0,527 .

Dari uraian diatas sehingga diperoleh persamaan regresinya adalah:

$$
\begin{gathered}
Y=a+b \cdot X \\
Y=14.402+0,527 X
\end{gathered}
$$


Hasil regresi diatas menunjukan bahwa jika tidak ada pemanfaatan internet (X) maka nilai konsisten minat kunjung (Y) adalah sebesar 14.402 dan apabila setiap penambahan $1 \%$ tingkat pemanfaatan internet $(\mathrm{X})$, maka minat kunjung $(\mathrm{Y})$ akan meningkat sebesar 0,527 .

\section{Uji Hipotesis}

Uji hipotesis adalah bagian dari pengujian hipotesis yang telah disusun sebelumnya. Untuk menguji hipotesis yang diajukan diterima atau ditolak, maka dilakukan uji hipotesis dengan langsung membandingkan t hitung dengan $t$ tabel. Bedasarkan pada hasil perhitungan dengan SPSS pada tabel 4.32 diketahui bahwa t hitung sebesar 5.405 dengan $\mathrm{n}=99$ dan taraf signifikan $0,01(10 \%)$ diperoleh nilai $\mathrm{dk}=\mathrm{n}-2=99-2=97$, maka t tabel sebesar 2,660. Dengan demikian t hitung lebih besar dari t tabel ( $\mathrm{t}$ hitung $>\mathrm{t}$ tabel) sehingga dapat disimpulkan bahwa Ho ditolak dan Ha diterima, yang berarti bahwa ada pengaruh signifikan antara manfaat internet $(\mathrm{X})$ terhadap minat kunjung $(\mathrm{Y})$.

\section{Koefisien Determinasi}

Dalam koefisien determinasi menggunakan aplikasi SPSS diperoleh hasil sebagai berikut:

Tabel 32. Koefisien Determinasi

(Model Summary ${ }^{\mathrm{b}}$ )

\begin{tabular}{|c|c|c|c|c|c|c|c|c|c|}
\hline \multirow[t]{2}{*}{ Model } & \multirow[t]{2}{*}{$\mathrm{R}$} & \multirow[t]{2}{*}{ R Square } & \multirow{2}{*}{$\begin{array}{l}\text { Adjusted R } \\
\text { Square }\end{array}$} & \multirow{2}{*}{$\begin{array}{l}\text { Std. Error } \\
\text { of the } \\
\text { Estimate }\end{array}$} & \multicolumn{5}{|c|}{ Change Statistics } \\
\hline & & & & & $\begin{array}{c}\text { R Square } \\
\text { Change }\end{array}$ & F Change & $\mathrm{df1}$ & df2 & $\begin{array}{c}\text { Sig. F } \\
\text { Change }\end{array}$ \\
\hline 1 & $.481^{a}$ & .231 & .224 & 4.28330 & .231 & 29.216 & 1 & 97 & .000 \\
\hline
\end{tabular}

a. Predictors: (Constant), Manfaat Internet

b. Dependent Variable: Minat Kunjung

Dari hasil di atas diketahui nilai $\mathrm{R}$ square sebesar 0,231. Nilai ini mengandung arti bahwa pengaruh pemanfaatan internet $(\mathrm{X})$ terhadap minat kunjung $(\mathrm{Y})$ adalah sebesar $23,1 \%$ sedangkan $76,9 \%$ minat kunjung dipengaruhi oleh variabel lain yang tidak diteliti.

\section{E. KESIMPULAN}

Berdasarkan analisis presentase skor pada variabel pemanfaatan internet diperoleh presentase skor sebesar $\mathbf{8 1 , 4 6 \%}$ berada pada interval $81,25 \%$ - 100\% yang berarti bahwa pemanfaatan internet termasuk dalam kategori sangat baik. Sedangkan minat kunjung diperoleh presentase skor sebesar $\mathbf{7 9 , 1 \%}$ berada pada interval 62,50\% - 81,24\% yang berarti bahwa minat kunjung termasuk dalam kategori baik. Berdasarkan uji regresi linier 
sederhana adanya pengaruh antara pemanfaatan internet dengan minat kunjung maka diperoleh persamaan $\mathrm{Y}=14.402+0,527 \mathrm{X}$, apabila setiap penambahan $1 \%$ tingkat pemanfaatan internet (X) maka minat kunjung (Y) akan meningkat sebesar 0,527. Berdasarkan uji hipotesis diperoleh thitung sebesar 5.405 dan nilai signifikan sebesar 0,00 maka Ho ditolak dan Ha diterima. Pada koefisien determinasi diketahui nilai $\mathrm{R}$ square sebesar 0,231 artinya pengaruh pemanfaatan internet (X) terhadap minat kunjung (Y) adalah sebesar $23,1 \%$ sedangkan 76,9\% minat kunjung dipengaruhi oleh variabel lain yang tidak diteliti.Berdasarkan penelitian yang telah dilakukan terdapat hubungan yang kuat antara pemanfaatan internet dengan minat kunjung.

Hal ini dilihat dari banyaknya mahasiswa yang memanfaatkan perpustakaan sebagai pusat sumber belajar dan pencarian informasi. Dengan memanfaatan internet memberi kemudahan berkomunikasi bagi pemustaka, memberi dukungan pembelajaran dalam membantu memenuhi kebutuhan informasi yang dibutuhkan dan memanfaatkan internet dapat membantu perpustakaan dalam meningkatkan layanannya.

\section{DAFTAR PUSTAKA}

Aditiyawarman, D. Analisis Pemanfaatan Wireless Hotspot bagi Pemenuhan Kebutuhan Informasi Pemustaka pada Perpustakaan Daerah Kabupaten Purwakarta. Program Studi Manajemen Informatika Akademi Manajemen Informatika dan Komputer BSI Karawang, (n.d.).

Habir. (2015). Pengaruh Layanan Perpustakaan terhadapMinat Kunjung Pemustaka di Perpustakaan STIKES Mega Rizky Makassar. Jurnal Ilmu Perpustakaa, Informasi dan Kearsipan.Vol. 3 No. 2. Sulawesi Selatan: Khizanah Al-Hikmah.Hartono. (2019). Manajemen Perpustakaan (Konsep Dasar, Dinamika dan Sustainable di Era Digita). Yogyakarta: Penerbit Gava Media.

Hartono. (2019). Manajemen Perpustakaan (Konsep Dasar, Dinamika dan Sustainable di Era Digita). Yogyakarta: Penerbit Gava Media.

Lasa, Hs. (2019). Kamus Kepustakawanan Indonesia. Yogyakarta: Pustaka Book Publisher. Sudibyo, Noerhayati. (1987). Pengelolaan Perpustakaan.Bandung: AlumniSugiyono. (2018). Metode Penelitian Kuanatitatif. Bandung: Penerbit Alfabeta. 